\title{
Losses associated with mortality of cattle and camels during transportation to Oko-Oba abattoir, Lagos State, Nigeria
}

\author{
Ademola A Ibironke (1,2), Cheryl ME McCrindle (1), Taiwo A Adejuwon (3), \\ Simeon IB Cadmus (4)
}

(1) Department of Paraclinical Studies, Faculty of Veterinary Medicine, University of Pretoria, South Africa; (2) Veterinary Department, Osun State Ministry of Agriculture \& Natural Resources, Nigeria; (3) Veterinary Department, Lagos State Ministry of Agriculture \& Cooperatives, Nigeria; (4) Department of Veterinary Public Health, Faculty of Veterinary Medicine, University of Ibadan Nigeria.

\begin{abstract}
Many food animals meant for slaughter arrive at the Agege abattoir and lairage daily to be produced into wholesome meat for human consumption. These animals generally get to the abattoir packed in Lorries and transported over long distances for many days to get to their destinations. Over a period of 36 months (three years), a total of 1179492 cattle and 11403 camels arrived for slaughter at the abattoir for human consumption. Over the same period, 1197 cattle and 27 camels died in the course of transportation due to the stress and inhumane treatment during transport. All the animals that arrived dead in transit had their carcass totally condemned and destroyed resulting in substantial losses to cattle traders, butchers and the general citizenry. Some of the reasons for these mortalities associated with transportation included overcrowding, long transportation without resting, stress, poor access road networks and traders not adhering to minimal space requirement for animal transportation in a bid to increase their profit margins. Failure to address the issue of proper transportation of food animals are likely to lead to more losses of food animals during transportation.
\end{abstract}

Key Words: abattoir, camel, cattle, Lagos, losses, Nigeria, transportation

European Journal Translational Myology - Basic Applied Myology 2010; 1 (1\&2): 13-16

\begin{abstract}
An integral part of making wholesome meat available for human consumption is the transportation of such food animals [7,9]. The consuming public, especially the urbanized populations are increasingly demanding better food animal production practices [1].

Lagos city is one of the most populous cities in Africa with an estimated population of 17 million citizens [14]. Animals slaughtered for human consumption in this state are mainly from the northern part of Nigeria as well as the neighboring African countries of Niger, Chad, Cameroon, Mali, and Burkina Faso. These animals arrive in Lagos mostly after several hours of traveling in heavily congested Lorries by road or sometimes even on hoof. This results in enormous stress to the animals $[6,21,22]$ due to elevated cortisol levels [20] with some of the animals dying as a result of the long period of stress. Stress prior to and during transportation has been attributed to factors including loading density and time spent during transport [19, $23,26,32]$, method of handling [11,30] and thermal stress [15,30,33]. Fasting and transportation also
\end{abstract}

decreases plasma triiodothyronine and hematocrit and increases plasma osmolarity thus disrupting homeostasis [2]. Research has shown that transport stress can reduce meat quality in food animals $[4,18,25]$ and that calm cows and bulls loose sensibility and collapse more quickly during slaughter than cattle with visible signs of agitation, thus leading to poorer meat quality [5,28]. Past researches have described varying mortality rates due to transport stress in different food animals. A $0.4 \%$ mortality rate was reported in pigs [29] while Malena et al., 2006 [16] reported $0.007 \%$ mortality rate in fattened cattle over an 8 year period. Malena et al., 2007 [17] has also reported mortality rates ranging between $0.0269 \%$ and 0.2562 for different categories of pigs and cattle between 1997 and 2006 in the Czech Republic.

This paper assesses the impact of transportation on the health and general well-being of the animals transported to the Oko-Oba, Agege, abattoir and lairage in Lagos, Nigeria. 
Impacts of transportation on food animals

European Journal Translational Myology - Basic Applied Myology 2010; 1 (1\&2): 13-16

\section{Materials and Methods}

Oko-Oba abattoir is the main abattoir serving the needs of providing wholesome meat to the Lagos populace and beyond and it is located at Agege, a suburb of Lagos metropolis on longitude $3^{\circ} 17^{\prime} 01^{\prime \prime}$ and latitude $6^{\circ} 39^{\prime} 32^{\prime \prime}$. It is one of the best organized abattoirs in Nigeria being run by the government though partnering with a private company (Harmony butcheries); thus its better organization. Hence, the abattoir is an example of the public sector and private cooperation for higher productivity. It receives thousands of animals daily. More than 1,000 cows and an average of 10 camels (between 5 and 15) are slaughtered at the abattoir on a daily basis, making the abattoir one of the busiest in the country. Animals slaughtered at the abattoir arrive by road from different parts of Nigeria including Ilesha Ibaruba (Kwara), Jebba, Kogi, Kwara, Niger, Sokoto, Bauchi, Adamawa, Maiduguri and many other towns within Nigeria. Other sources of animals slaughtered at the abattoir are countries mainly within the West African sub-region including Niger, Chad, Cameroon, Mali, Burkina Faso, Togo and many other countries. More animals are slaughtered at the abattoirs during festive periods than other periods of the year and the lorries (transporting) the animals are sometimes too densely packed with animals in order to maximize space and hence profits. The data for this study were based on abattoir records kept by both the Veterinary Department of the state as well as the private managers of the abattoir. The survey was a retrospective study spanning over a period of 3 years (August, 2004 to August, 2007). The abattoir was also visited on a daily basis between 15th November, 2007 and 15th January, 2008) to gain first hand experience on the scope of the problems and to witness all the activities that take place from the arrival of the animals to slaughter. Special attention was paid to the mode of transportation and handling of the animals to assess the level of humaneness of these processes. Those involved in the transportation of the animals were also orally interviewed to determine the source of the animals and duration of time it took to get to their destination as well as their level of compliance with the recommended space per animal during road transport.

\section{Results and Discussion}

A total of 1170492 cattle and 11403 camels were slaughtered at this abattoir over the survey period with the monthly slaughter figure ranging between 21875 and 30070 for cattle and 144 and 455 for camels. A total of 1224 animals including 1197 cattle $(0.10 \%)$ and 27 camels $(0.24 \%)$ died during transportation or shortly after arrival at the abattoir as a result of transport stress (Table 1) and were therefore totally condemned and destroyed by meat inspection officers. Transport of food animals from the production point to the abattoir for processing into wholesome meat is an important aspect of providing wholesome meat to consumers and requires a measure of care and discipline to perform. It was discovered from the transporters that the animals were generally fasted prior to transportation and that they were kept standing for more than 72 hours while the journey lasted. The space requirement for transportation of food animals was also not complied with even though slaughter cows, unlike pigs, sheep and calves prefer to stand during transport and hence require less space during transportation [24,31]. The animals were also packed too densely during transportation with cattle and camels in the lower cabin and small ruminants placed above them being separated by dry bamboo sticks in the same lorry. Stops were also not made and the control posts meant to allow for resting and inspection of the animals only served as revenue collection points and treated as such by animal traders and transporters. All these result in undue stress on the animals $[6,12,21,22,24,31]$ with animals developing elevated blood cortisol levels [20] and many animals arriving at the destination moribund or dead. Stress induced by inhumane transportation of food animals has also been shown to reduce the quality of meat produced from such animals $[4,25,12]$ hence, resulting in provision of poor quality meat to the consuming public. This leads

TABLE 1. Mortalities in food animals resulting from transport stress

\begin{tabular}{|c|c|c|c|c|c|c|c|}
\hline Period & $\begin{array}{c}\text { No. of } \\
\text { cattle } \\
\text { slaughtered }\end{array}$ & $\begin{array}{c}\text { No. of } \\
\text { cattle dead } \\
\text { in transit }\end{array}$ & $\begin{array}{c}\text { \% of } \\
\text { cattle } \\
\text { dead in } \\
\text { transit }\end{array}$ & $\begin{array}{c}\text { No. of } \\
\text { camels } \\
\text { slaughtered }\end{array}$ & $\begin{array}{c}\text { No. of } \\
\text { camels } \\
\text { dead in } \\
\text { transit }\end{array}$ & $\begin{array}{c}\text { \% of } \\
\text { camels } \\
\text { dead in } \\
\text { transit }\end{array}$ & $\begin{array}{c}\text { Total no. of } \\
\text { animals dead } \\
\text { in transit }\end{array}$ \\
\hline $\begin{array}{c}\text { Aug 2004 } \\
\text { Dec 2004 }\end{array}$ & 156953 & 56 & 0.036 & 887 & 4 & 0.45 & 60 \\
\hline Jan 2005 & 381855 & 577 & 0.15 & 3642 & 5 & 0.13 & 582 \\
Dec 2005 & 402139 & 305 & 0.076 & 4334 & 11 & 0.25 & 316 \\
\hline $\begin{array}{c}\text { Jan 2006 } \\
\text { Dec 2006 }\end{array}$ & 229545 & 259 & 0.113 & 2540 & 7 & 0.28 & 266 \\
\hline $\begin{array}{c}\text { Jan 2007 } \\
\text { Aug 2007 }\end{array}$ & 1179492 & 1197 & 0.10 & 11403 & 27 & 0.24 & 1224 \\
\hline
\end{tabular}




\section{Impacts of transportation on food animals}

European Journal Translational Myology - Basic Applied Myology 2010; 1 (1\&2): 13-16

to great losses to the farmers, the traders, the butchers and the entire country.

Furthermore, Lagos-Ibadan expressway is the only major road leading to the state from the various points of animal purchase, which also serves other transporters. Thus the incessant traffic jams experienced on the road. This therefore increases the time the animals spend on the road. It is often quite common to see the animal owners slaughter and attempt to sell animals that are almost dying by the roadsides on such occasions to avoid complete loss.

Based on the outcome of this study, it is important to re-evaluate the transportation of food animals to abattoirs not only in Lagos State, but also other parts of the country. The losses incurred due to mortality of animals during transport are too enormous to ignore and steps must be taken to stem this tide. It is thus recommended that the government construct more link roads into the State in order to ease the course of transport to the state.

It is on this note that the following recommendations are made:

1. The recommended spacing for transport of food animals must be enforced and complied with by livestock owners and transporters.

2. Animals should be provided with adequate food and water prior to and during transportation.

3. Veterinary and animal health officers at control post must not only be revenue collectors but do actual inspection of animals being carried across the various state borders and ensure that recommended standards for transport of food animals are complied with. Stressed and sick animals should be detained.

4. Research has shown that giving electrolyte solutions to animals during handling and transport can greatly reduce handling and transport stress on the animals $[12 ; 21 ; 22 ; 25]$. An adaptation of this principle (e.g. feeding salt and sugar solution to animals prior to transportation) may be considered for use in transporting animals in Nigeria if it will not excessively increase cost of production.

5. More link roads into Lagos should be constructed by government in order to de-congest the LagosIbadan express way and ensure smoother transportation of animals into Lagos. Other roads that already exist like the Ikorodu, Epe and SangoOtta roads should also be upgraded into dual carriage of expressways in order to decongest the Lagos-Ibadan express way thus making for smoother transportation of animals.

6. Alternative transportation system for transporting food animals may also be considered such as reviving the Nigerian Railways system or using the inland waterways to transport animals faster, safer more humane and more hygienic.

\section{Acknowledgements}

We wish to thank the staff of the Lagos State Ministry of Agriculture and Cooperatives (Veterinary Department) as well as the staff of Harmony Butcheries for their assistance on this survey.

\section{Corresponding Author}

Ademola Ibironke, Veterinary Department, Osun State Ministry of Agriculture \& Natural Resources, Nigeria. E-mail: ademolaibironke@yahoo.com

\section{References}

[1] Appleby MC, Hughes BO. Introduction. In: Animal Welfare. MC Appleby, BO Hughes (Eds.) Wallingford: CAB International, UK 1997.

[2] Becker BA, Mayes, HF, Hahn GL, Nienabers JA, Jesse GW, Anderson ME, Heymann H, Hederick, HB. Effect of fasting and transportation on various physiological parameters and meat quality of slaughter hogs. J Anim Sci 1989; 67: 334-341.

[3] Debut M, Berri C, Baeza E, Sellier N, Arnould C, Le Bihan-Duval E. Variation of chicken technological meat quality in relation togenotype and pre-slaughter stress conditions. Poult Sci 2003; 82: 1829-1838.

[4] Gisperta M, Faucitano L, Olivera MA, Guardiaa MD, Colla C, Siggens K, Harvey K, Diestre A. A survey of pre-slaughter conditions, halothane gene frequency, and carcass and meat quality in five Spanish pig commercial abattoirs. Meat Sci 1999; 48: 237-247.

[5] Grandin T. Euthanasia and slaughter of livestock. J Am Vet Med Asso 1994; 204: 1354-1360.

[6] Grandin T. Assessment of stress during handling and transport. J Anim Sci 1997; 75(1): 249-257.

[7] Gregory NG. Preslaughter handling, stunning and slaughter. Meat Sci 1994; 36: 45-56.

[8] Gregory NG. Welfare and hygiene during preslaughter handling. Meat Sci 1996; 43(Suppl. S): S35-S46.

[9] Gregory NG. Animal welfare and meat science. CABI Publishing, Wallingford, UK. 1998.

[10] Kannan G, Heath JL, Wabeck CJ, Souza MCP, Howe JC, Mench JA. Effect of crating and transport on meat quality characteristics in broilers. Poult Sci 1997; 76: 523-529.

[11] Knowls TG and Broom DM. The handling and transport of broilers and spent hens. Appl Anim Behav Sci 1990; 28: 75-91.

[12] Knowles TG. A review of the road transport of cattle. Vet Rec 1999; 144 (8): 197-201.

[13] Kozak A, Vecerek V, Chloupek P, Tremlova B Malens M. Veterinary meat inspection of pig carcasses in the Czech Republic during the period 


\section{Impacts of transportation on food animals}

European Journal Translational Myology - Basic Applied Myology 2010; 1 (1\&2): 13-16

of 1995-2002. Vet Med-Czech 2003; 48: 207213.

[14] Lagos State Government. Lagos State Government Web page (2007). Available at http://www.lagosstate.gov.ng/c/portal/layout?p_1_ id=PUB.1095.7. 2007; Accessed on 7th March, 2008.

[15] Maccalium JM, Abeyesinghe SM, White RP, Wathes CM. A continuous-choice assessment of the domestic fowls aversion to concurrent transport stressors. Anim Welf 2003; 12: 95-107.

[16] Malena M, Voslarova E, Tomanova P, Lepkova $\mathrm{R}$, Benadova I, Vecerek V. Influence of travel distance and the season upon transport-induced mortality in Fattened cattle. Acta Vet Brno 2006; 75: 619-624.

[17] Malena M, Voslarova E, Kozak A, Belobradek P, Bedanova I, Steinhauser L, Vecerek V. Comparison of mortality rates in different categories of Pigs and cattle during transport for slaughter. Acta Vet Brno 2007; 76: 109-116.

[18] Mcglone JJ. Animal handling makes a difference. Pork '97 1997; (September Issue) page 27.

[19] Nijdam E, Arens P, Lambooij E, Decypere E, Stegeman JA. Factors influencing bruises and mortality of broilers during catching, transport and lairage. Poult Sci 2004; 83: 1610-1615.

[20] Nyberg L, Lundstrom K, Edfors-lilja I, Rundgren M. Effects of transport stress on concentrations of cortisol, corticosteroid-binding globulin and glucocorticoid receptors in pigs with different halothane genotypes. J. Anim Sci 1998; 66: 12011211.

[21] Parker AJ, Dobson GP, Fitzpatrick LA. Physiological and metabolic effects of prophylactic treatment with osmolytes glycerol and butaine on Bos indicus steers during long duration transportation. J Anim Sci 2007; 85: 2916-2923.

[22] Parker AJ, Hamlin, GP, Coleman CJ, Fitzpatrick LA. Quantitative analysis of acid-base balance in Bos indicus steers subjected to transportation of long duration. J Anim Sci 2003; 81(6): 1434 1439.

[23] Perremans S, Geers R. Effect of transport on some welfare characteristics of slaughter pigs. Vlaams Diergenskund Tijds 1996; 65: 310-317.
[24] Ritter MJ, Ellis M, Brinkmann J, Dedecker JM, Keffaber KK, Kocher ME, Peterson BA, Schlipf JM, Wolter BF. Effect of floor space during transport of market-weight pigs on the incidence of transport losses at the packing plant and the relationships between transport conditions and losses. J Anim Sci 2006; 84(10): 2856-2864.

[25] Schaefer AL, Jones SD, Stanley RW. The use of electrolyte solutions for reducing transport stress. J Anim Sci 1997; 75(1): 258-265.

[26] Suchy P, Bedanova I, Vecerek V, Voslarova E, Pisteklova V, Chloupek P, VitulaIa F. Effect of transport stress and floor space reduction on selected biochemical indices in common pheasant (Phasianus colchicus), Arch Geflugelkd 2007; 71: 56-61.

[27] Taubert E, Wicke M, Von Lengerken G, Troeger K. Relationship between external factors and meat quality of turkeys- Influence of external stress factors on the glycolysis. Fleischwirtschaft 2002; 82: 96-99.

[28] Voisnet BD, Grandin T, O'Connor SF, Tatum JD, Deesing MJ. Bos indicus cattle with excitable temperaments have tougher meat and a higher incidence of borderline dark cutters. Meat Sci 1997; 46: 367-377.

[29] Von Altrock A, Von Holleben K. Sudden death in fattening herds on taking blood samplesExperiences from the practice. Berliner Munchener Tierarztl Wochenschr 1999; 112: 8690.

[30] Voslarova E, Janakova B, Rubesova L, Kozak A, Bedanova I, Steinhauser L, Vecerek V. Mortality rates in poultry species and categories during transport for slaughter. Acta Vet Brno 2007; 76: 101-108.

[31] Warriss PD. Choosing appropriate space allowances for slaughter pigs transported by road: a review. Vet Rec 1998; 142(17):449-454.

[32] Warriss PD, Bevis EA, Brown SN, Edwards JE. Longer journeys to processing plants are associated with higher mortality in broilerchickens. Br Poult Sci 1992; 33: 201-206.

[33] Werner C, Reiners K, Wicke M. Mortality rates during transport of slaughter pigs. Fleischwirtschaft 2005; 85: 136-136. 